\title{
Evaluation of Various Fungitoxicants and Bio-Agents in the Laboratory and Field against Leaf Spot and Fruit Rot of Chilli caused by Alternaria alternata (Fries) Keissler
}

\author{
Manjul Pandey $^{1 *}$, P.K. Dwivedi' ${ }^{2}$, R.P. Mishra ${ }^{3}$ and Mukesh Srivastava ${ }^{3}$
}

${ }^{1}$ Krishi Vigyan Kendra, Banda, Banda University of Agriculture and Technology, Banda210001(UP), India

${ }^{2}$ Krishi Vigyan Kendra, Raisen (MP), India

${ }^{3}$ Department of Plant Pathology, C. S. Azad University of Agriculture \& Technology, Kanpur208002(India), India

*Corresponding author

\section{A B S T R A C T}

\section{Keywords}

Chilli (Capsicum

annuum),

Fungitoxicant, Bioagent, Management, Alternaria alternata, Leaf spot, Fruit rot A

Article Info

Accepted:

17 December 2018

Available Online:

10 January 2019
Out of twelve fungicides and three bio-agents screened in the laboratory, Bavistin, Indofil M-45, Chlorothalonil, Vitavax and Thiram proved most effective as they caused total inhibition of the pathogen. Indofil Z-78, Captafol, Ziram, Captan and Blitox-50 were also found to be significantly superior compared to other fungicides. Out of five seed dressing fungicides and three bio-agents, Trichoderma viride proved to be the most effective followed by Trichoderma harzianum, Bavistin and Thiram in controlling the seed -borne infection of Alternaria alternata. However, none of the seed dressing fungicides was found effective in checking the secondary spread of the disease under field conditions. Out of eight spray fungicides, Indofil M-45 proved to be most effective in controlling the disease in pot culture experiment as well as in field trials, followed by Indofil Z-78 and Chlorothalonil. Application of Indofil M-45@ $0.2 \%$ can be recommended for the successful management of Alternaria leaf spot and fruit rot due to Alternaria alternata under field conditions.

\section{Introduction}

Chilli is a unique crop among all the spices being the only source of capsaicin (Tiwari, 1990). Chillies are the best and the cheapest source of vitamin $\mathrm{C}$ and $\mathrm{A}$. The green chillies also contain rutin $\left(\mathrm{C}_{27} \mathrm{H}_{30} \mathrm{O}_{16}\right)$, which has specific medicinal value (Purseglove, 1977).
The pungency of chilli is due to an alkaloid, "Capsaicin $\left(\mathrm{C}_{18} \mathrm{H}_{27} \mathrm{NO}_{3}\right)$." The red colour in fruit at the ripening stage is due to the pigment Capsanthin (Nath, 1969). Chilli is valued throughout the world for pungency. The pungent principle of red pepper consists of a mixture of seven closely related allyl vanillyamides named Capsaicinoides, which 
are separated by solvent extraction of the dried fruits and the subsequent removal of the solvent (Tiwari, 1990; Govindrajan, 1985; Maya, 1975).

The chilli crop suffers due to a number of fungal, bacterial and viral diseases, which render its production into stake (Mukherji and Bhasin, 1986; Singh, 2003; Agrios, 2004). Among the various fungal diseases leaf spot, fruit rot incited by Alternaria alternata (Fr.) Keissler is becoming a limiting factor and posing a major problem in Kanpur and adjoining areas (Narain et al., 2000). The pathogen has been reported to cause seed, seedling, leaf and fruit diseases (Sreekantiah et al., 1973; Mehrotra, 1980; Alam et al., 1981; Singh, 2003). Post harvest decay of fruits and seeds has also been recorded due to this pathogen (Leyendecker, 1954 a; Mathur and Agnihotri, 1961; Spalding and King, 1981).

\section{Materials and Methods}

For the control of disease, the effect of different fungitoxicants bio-agents and foliar application of fungitoxicants were adopted in the present investigation. However, the efficacy of various fungitoxicants belonging to different groups were first ascertained in bioassay test against the pathogen in the laboratory and those found effective were used further for experiments in pots/field for control of the disease. The procedures adopted in these studies were as follows:

\section{Laboratory bio-assay of different fungitoxicants}

The relative efficacy of twelve fungicides was tested against pathogen under laboratory conditions. For this purpose, poison-food technique devised by Schmitz, (1930) was followed for bioassay test of fungitoxicants. The requisite quantities of fungitoxicants were incorporated into 2 per cent sterilized unsolidified Potato dextrose agar and shaken well to make it homogenous. Medium was then poured in $90 \mathrm{~mm}$. sterilized Petridishes with three replications of each treatment and allowed to solidify. These dishes were then inoculated with $5 \mathrm{~mm}$ circular discs of inoculum from 10 days old culture and this disc was placed in the centre of each Petridish in such a way so that fungus may come in direct contact with the medium. The medium, without any fungitoxicants poured and inoculated similarly served as control. The Petridishes were incubated at $28 \pm 1^{\circ} \mathrm{C}$ for 10 days. The efficacy of various fungitoxicants was assessed by measuring the radial growth of the fungal colony in $\mathrm{mm}$.

The fungitoxicants, which were found effective in laboratory evaluations, were employed further tried in two way namely, as seed dressers as well as spray fungitoxicants.

Growth inhibition percentage of colony was calculated by formula given below (Bliss, 1934):

$$
I=\stackrel{C-T}{X} 100
$$

Where,

$\mathrm{I}=$ Inhibition percentage of colony

$\mathrm{C}=$ Average diameter of colony in control

$\mathrm{T}=$ Average diameter of colony in treatment

\section{Bio-assay of bio-agents}

Soil samples from the Rhizosphere were taken from 3 places of the field and mixed well to make fine particles. Collection of soil samples were made for the root zone at $5-15 \mathrm{~cm}$ depth.

Ten gram of mixed soil samples was taken in a measuring cylinder and added $100 \mathrm{ml}$ of sterile distilled water, shacked it well to make homogenous mixture $(1: 10)$. Now took one ml 
from the mixture and $9 \mathrm{ml}$ of sterile water in tube to make solution of (1:100). Likewise, its serial dilutions were added to get 1:10,000 strength in such a way so as to transfer one $\mathrm{ml}$. of this suspension to sterile Petriplates and poured Potato dextrose agar medium in the Petriplates. Shaked well the plate gently an allowed it to solidify. Now these Petriplates were incubated at room temperature. Observations were recorded after 4-5 days after development of colonies.

The antagonistic properties of bio-agents namely Trichoderma viride, Trichoderma harzianum and Pseudomonas flourescens were tested by dual culture plate technique. Inoculation of bio-agents against test fungus was made from 10 day old culture of bio-agent and test fungus. The $5 \mathrm{~mm}$ disc of bio-agents and test organism were cut by a cork borer and bio-agents bits at one edge of the Periplates and test organism at another edge of the same Petriplates were placed. The inoculated Petridishes were kept incubator at $28 \pm 1^{\circ} \mathrm{C}$ for 10 days and observations were taken accordingly (Vincent, 1927).

\section{Elimination of seed borne infection}

Repeated isolations from chillie seeds have yielded the fungus $A$. alternata. It was therefore, considered useful to test some fungicides against this pathogen associated with the seed.

To test the efficacy of different fungicides in controlling the seed-borne infection, naturally infected seeds of the variety 'Chaman' were tested with different fungicides. The fungicides used for seed treatment were Bavistin (0.1\%), Thiram (0.2\%), Captan (0.2\%), Captafol (0.2\%) Ziram (0.2\%) and Vitavax $(0.1 \%)$. Thorough seed dressing was done by shaking the seed in plugged conical flasks with requisite quantity of fungicide for 20 minutes. One hundred seeds from each treated lot were transferred to sterilized moist blotters and the experiment was repeated three times. Thus, four hundred seeds in all were taken for each treatments, keeping separate set of untreated seeds as 'Control'. Observations on the appearance of fungal growth on seeds and seedlings were recorded after 10 days of incubation at $28 \pm 1^{\circ} \mathrm{C}$. Percentage infection in each treatment was noted.

To determine the efficacy of various seed dressing fungicides under field conditions, for controlling the disease, ten treated seeds from each lot were sown in $30 \mathrm{~cm}$ diameter earthen pots in three replications. Pots sown with untreated seeds served as control. Five plants were maintained in each pot. Pots were kept in glass house chamber for protection against aerial infection. Observations on disease intensity were recorded after the plants had attained the age of two months.

\section{Fungitoxicants spray}

The spray fungicides found effective in vitro were further employed in fungicidal control trials conducted during 2001-02 in pot culture and during 2002-03 and 2003-04 in field experiments for the control of Alternaria leaf spots and fruit rot of chilli.

\section{Evaluation of fungicides in pot culture experiments}

The seeds of a highly susceptible chillie variety Chaman were sown in $30 \mathrm{~cm}$ pots and after attaining the age of 30 days, these seedlings were transplanted in other pots in three replications. In each pot, five plants were maintained. After attaining the age of two months from the date of sowing, the plants were inoculated with mycelial-cum-spore suspension of the pathogen. Spraying of the fungicides was started just after 48 hours of inoculation and repeated at an interval of 15 days with four subsequent sprays. A set of 
unsprayed pots served as control. was transformed into angle $=\sin ^{1} \sqrt{ }$ per cent Observations on disease intensity were disease intensity and then analyzed recorded on the basis of percentage leaf area infected after 15 days of last spraying, by statistically. The percentage of disease control randomly selecting 25 leaves from each over check was calculated as bellow: replication. The percentage disease intensity

Disease intensity in control — Disease intensity in treatment

Per cent disease control $=$

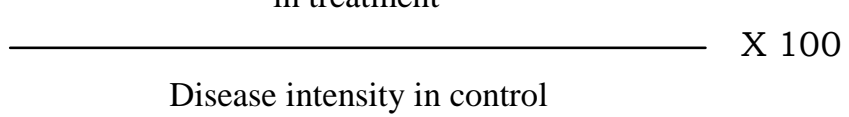

\section{Evaluation of fungicides in field trial}

Field trials were conducted with same set of spray fungicides by sowing chilli Chaman variety. The experiment was laid out in randomized block design with three replications. The transplanting of one month old seedlings in the plots was done is the last week of July in both the years. The size of the plots was $4.5 \mathrm{~m} \times 3.0 \mathrm{~m}$ and the spacing between the rows and the plants were $75 \mathrm{~cm}$ and $60 \mathrm{~cm}$, respectively. Sixty days old plants were artificial inoculated by spraying mycelial-cum-spore suspension of the pathogen and the plots were irrigated from time to time, to maintain proper moisture. The first fungicidal spraying was started just after 48 hours of inoculation and repeated at an interval of 15 days with four subsequent sprays. The control plots were sprayed with water only. For recording the disease intensity, one hundred randomly selected leaves per replication were examined after 15 days of the last spray and the disease intensity was calculated according to the formula given under pot culture experiment. Fruits were also picked periodically.

\section{Results and Discussion}

\section{Laboratory screening of fungicides/bio- agents against the pathogen}

In order to select suitable fungicides/bioagents against the pathogen, 12 fungicides and
3 bio-agents were tested on two per cent Potato dextrose agar medium under laboratory conditions using the techniques described by Schmitz (1930) for chemical and Vincent (1927) for bio-agents. Each treatment was replicated three times in $98 \mathrm{~mm}$ Petridishes. Culture medium without any fungicides served as control. The inoculated Petridishes were incubated at $28 \pm 1^{\circ} \mathrm{C}$ for 10 days and the data on radial growth were recorded for each treatment separately. Per cent inhibition over control was calculated and data were analysed statistically and presented in Table 1 .

The results presented in Table 1, indicated that all the fungicides and bio-agents tested were significantly superior to the control (check) in inhibiting the growth of Alternaria alternata. Out of 12 fungitoxicants and 3 bio-agents tested, only five fungicides viz., Bavistin, Indofil M-45, Chlorothalonil, Vitavax and Thiram proved to be effective fungicides as they inhibited the growth of the pathogen completely.

The remaining fungicides/bio-agents in order to their decreasing inhibitory effect against the pathogen were Indofil Z-78, Captafol, Ziram, Captan, Blitox-50, Kitazin, Topsin M, Trichoderma viride, Trichoderma harzianum and Pseudomonas flourescens and they differed significantly from one another in checking the growth of the pathogen (Fig. 1). The chilli plant harbours the infection of Alternaria alternata through diseased seeds or 
from the diseased debris of the previous crop left over in the soil or from the conidia borne on the affected aerial parts of the standing crop. In each case, it is necessary to protect the plants by timely application of fungicides and bio-agents for spread of the disease. As such, the efficacy of various fungicides/bioagents, adjudged to be the best in the laboratory tests was further ascertained both by applying them as seed dressers before sowing and using them as spray fungicides.

\section{Seed treatment}

Five seed dressing fungicides and three bioagents which proved most effective in the laboratory screening were tried to assess their efficacy in eliminating the seed borne infection of Alternaria alternata (Table 2). The results of the Table 2 and Figure 2 reveal that Trichoderma viride proved to be the most effective bio-agent followed by Trichoderma harzianum,

Table.1 Inhibitory effect of various fungitoxicants and bio-agents on growth of Alternaria alternata in bio-assay test

\begin{tabular}{|c|c|c|c|c|}
\hline $\begin{array}{l}\text { S. } \\
\text { No. }\end{array}$ & Fungicides/bio-agents & Dose $(\%)$ & $\begin{array}{l}\text { Av. diameter of } \\
\text { fungal colony } \\
(\mathrm{mm})\end{array}$ & $\begin{array}{c}\text { Inhibition over } \\
\text { control }(\%)\end{array}$ \\
\hline (A) & \multicolumn{4}{|l|}{ Fungicides } \\
\hline 1. & Bavistin & 0.1 & 0.0 & $100.0(90.0)$ \\
\hline 2. & Indofil M-45 & 0.2 & 0.0 & $100.0(90.0)$ \\
\hline 3. & Chlorothalonil & 0.2 & 0.0 & $100.0(90.0)$ \\
\hline 4. & Vitavax & 0.1 & 0.0 & $100.0(90.0)$ \\
\hline 5. & Thiram & 0.2 & 0.0 & $100.0(90.0)$ \\
\hline 6. & Indofil Z-78 & 0.2 & 2.7 & $97.0(88.9)$ \\
\hline 7. & Captafol & 0.2 & 5.3 & $94.1(84.3)$ \\
\hline 8. & Ziram & 0.2 & 8.7 & $90.3(79.8)$ \\
\hline 9. & Captan & 0.2 & 12.0 & $86.6(75.5)$ \\
\hline 10. & Blitox -50 & 0.2 & 16.7 & $81.4(71.6)$ \\
\hline 11. & Kitazin & 0.2 & 19.2 & $78.6(69.4)$ \\
\hline 12. & Topsin $-\mathrm{M}$ & 0.2 & 24.6 & $72.6(64.9)$ \\
\hline \multicolumn{5}{|c|}{ (B) Bio-agents } \\
\hline 13. & Trichoderma viride & $\mathrm{Cfu}^{10^{6}} / \mathrm{g}$ & 25.3 & $71.8(64.4)$ \\
\hline 14. & Trichoderma harzianum & $\mathrm{Cfu}^{10^{6}} / \mathrm{g}$ & 28.1 & $68.7(62.2)$ \\
\hline 15. & Pseudomonas flourescens & $\mathrm{Cfu}^{10^{22}} / \mathrm{g}$ & 32.4 & $64.0(59.0)$ \\
\hline 16. & Control & & 90.0 & \\
\hline
\end{tabular}

C.D. at $5 \%$ level of significance $=1.70$

S.E. $(D)=0.83$ 
Table.2 Efficacy of different fungicides/bio-agents against seed borne infection of Alternaria alternate

\begin{tabular}{|l|l|c|c|c|}
\hline $\begin{array}{c}\text { S. } \\
\text { No. }\end{array}$ & \multicolumn{1}{|c|}{ Fungicides/ bio-agents } & Dose $(\%)$ & \multicolumn{1}{|c|}{$\begin{array}{c}\text { Per cent } \\
\text { disease } \\
\text { infection }\end{array}$} & $\begin{array}{c}\text { Per cent } \\
\text { infection } \\
\text { over control }\end{array}$ \\
\hline 1. & Bavistin & 0.1 & $10.8(21.3)$ & $84.4(70.8)$ \\
\hline 2. & Thiram & 0.2 & $12.3(22.8)$ & $77.7(68.7)$ \\
\hline 3. & Captan & 0.2 & $16.9(26.9)$ & $69.3(62.6)$ \\
\hline 4. & Captafol & 0.2 & $20.1(29.5)$ & $63.5(58.7)$ \\
\hline 5. & Ziram & 0.2 & $26.5(34.4)$ & $62.8(58.2)$ \\
\hline 6. & Trichoderma viride & $\mathrm{Cfu}^{10^{6}} / \mathrm{gm}$ & $9.7(20.1)$ & $82.4(72.4)$ \\
\hline 7. & Trichoderma harzianum & $\mathrm{Cfu}^{10^{6}} / \mathrm{gm}$ & $10.3(20.7)$ & $81.3(71.5)$ \\
\hline 8. & Pseudomonas flourescens & $\mathrm{Cfu}^{10^{22}} / \mathrm{gm}$ & $12.6(23.1)$ & $77.1(68.2)$ \\
\hline 9. & Control & - & $55.2(53.3)$ & \\
\hline
\end{tabular}

C.D. at $5 \%$ level of significance $=2.27$

S.E. $(\mathrm{D})=1.08$

Table.3 Efficacy of fungicides on the severity of the disease caused by Alternaria alternata in pot culture experiment during 2001-02

\begin{tabular}{|c|c|c|c|c|}
\hline $\begin{array}{c}\text { S. } \\
\text { No. }\end{array}$ & Fungicides & Dose (\%) & $\begin{array}{c}\text { Per cent } \\
\text { disease } \\
\text { intensity }\end{array}$ & $\begin{array}{c}\text { Per cent } \\
\text { infection } \\
\text { over control }\end{array}$ \\
\hline 1. & Indofil M-45 & 0.2 & $28.6(35.9)$ & $62.7(58.2)$ \\
\hline 2. & Indofil Z-78 & 0.2 & $31.2(37.7)$ & $59.3(56.0)$ \\
\hline 3. & Chlorothalonil & 0.2 & $33.5(39.2)$ & $56.3(54.0)$ \\
\hline 4. & Bavistin & 0.1 & $38.1(42.3)$ & $50.3(50.2)$ \\
\hline 5. & Blitox -50 & 0.2 & $39.4(43.2)$ & $48.6(49.1)$ \\
\hline 6. & Captafol & 0.2 & $40.2(43.7)$ & $47.6(48.5)$ \\
\hline 7. & Kitazin & 0.2 & $42.5(45.2)$ & $44.6(46.5)$ \\
\hline 8. & Topsin - M & 0.2 & $44.3(4.3)$ & $42.3(45.0)$ \\
\hline 9. & Control & & $76.8(68.0)$ & \\
\hline
\end{tabular}


Table.4 Effect of fungicides spraying on the disease intensity of Alternaria leaf spot and fruit rot disease of chilli

\begin{tabular}{|c|c|c|c|c|c|c|}
\hline \multirow[t]{2}{*}{$\begin{array}{l}\text { S. } \\
\text { No. }\end{array}$} & \multirow[t]{2}{*}{$\begin{array}{l}\text { Name of } \\
\text { fungicides }\end{array}$} & \multirow[t]{2}{*}{$\begin{array}{l}\text { Dose } \\
(\%)\end{array}$} & \multicolumn{2}{|c|}{ Disease intensity (\%) } & \multicolumn{2}{|c|}{$\begin{array}{c}\text { Percentage disease } \\
\text { control }\end{array}$} \\
\hline & & & 2002-03 & 2003-04 & 2002-03 & 2003-04 \\
\hline 1. & Indofil M-45 & 0.2 & $17.3(24.5)$ & $16.5(23.9)$ & $65.1(59.7)$ & $65.5(60.0)$ \\
\hline 2. & Indofil Z-78 & 0.2 & $18.3(25.3)$ & $19.6(26.2)$ & 63.1(58.4) & $58.5(55.6)$ \\
\hline 3. & Chlorothalonil & 0.2 & $19.5(26.2)$ & $20.3(26.7)$ & $60.6(56.7)$ & $57.0(54.5)$ \\
\hline 4. & Bavistin & 0.1 & 20.7(27.0) & $19.3(26.0)$ & $58.2(55.2)$ & $59.1(56.2)$ \\
\hline 5. & Blitox -50 & 0.2 & $25.6(30.3)$ & $27.8(31.8)$ & 48.3(48.9) & $41.2(44.3)$ \\
\hline 6. & Captafol & 0.2 & $35.3(36.4)$ & $34.2(35.7)$ & $28.8(36.9)$ & $27.3(35.2)$ \\
\hline 7. & Kitazin & 0.2 & $37.4(37.7)$ & $38.7(38.4)$ & 24.3(32.0) & $19.0(28.7)$ \\
\hline 8. & Topsin - M & 0.2 & $38.5(38.3)$ & $40.3(39.4)$ & $22.3(32.0)$ & 14.7(25.0) \\
\hline 9. & Control & $\begin{array}{l}\text { Water } \\
\text { spray }\end{array}$ & $49.6(44.7)$ & $47.3(43.4)$ & - & - \\
\hline & $\begin{array}{l}\text { Dat5\% level of significan } \\
\text { E. (D) }=1.17\end{array}$ & $\begin{array}{l}=2.49 \\
1.35\end{array}$ & 2.86 & & & \\
\hline
\end{tabular}

Fig.1

Fig. 1: Inhibitory effect of differnet fungicides and bio-agents on growth of Alternaria alternata in vitro after 10 days of incubation at $28 \pm 1^{\circ} \mathrm{C}$.

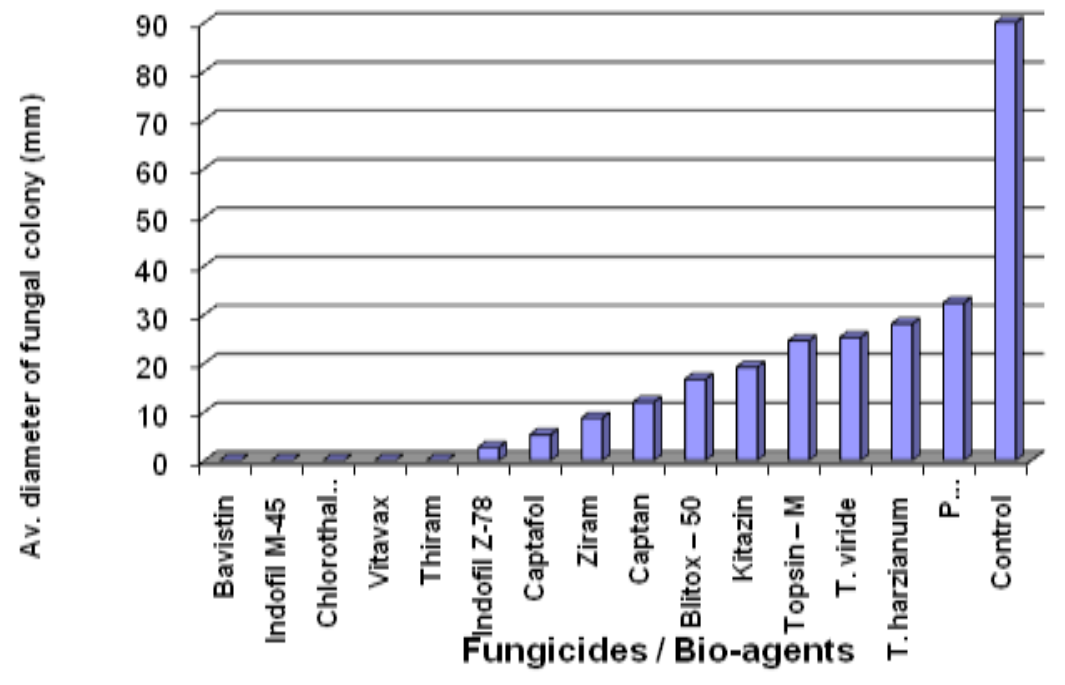


Fig.2

Fig. 2: Efficacy of different fungicides/bio-agents against seed borne infection of Alternaria alternata

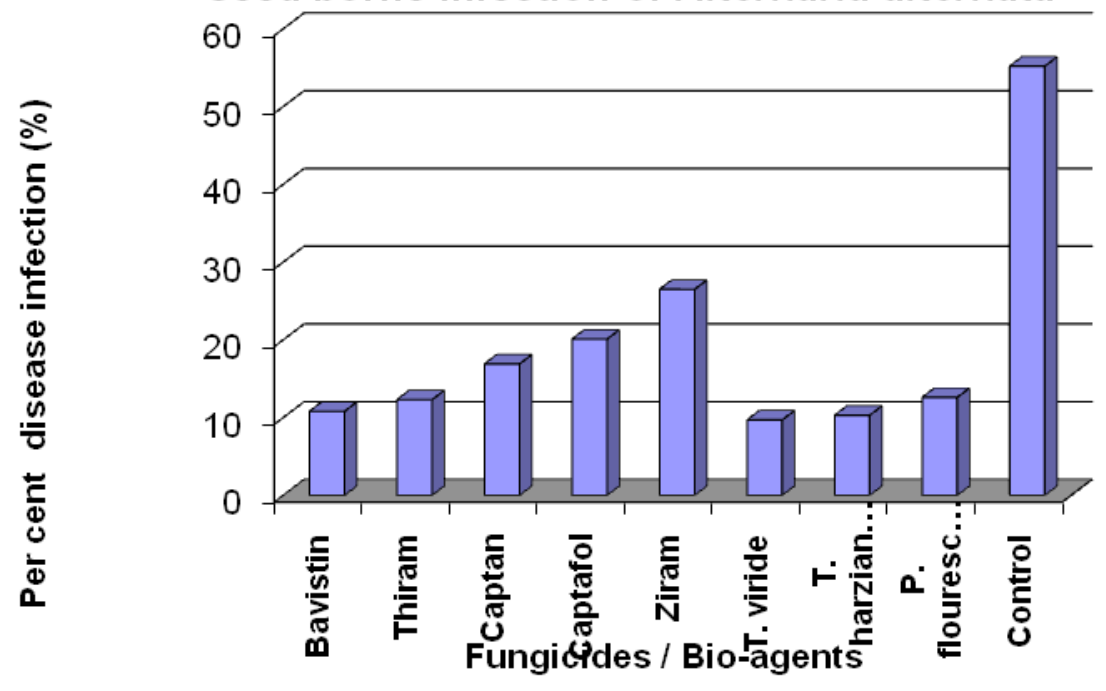

Fig.3

Fig. 3: Efficacy of fungicides on the severity of the disease caused by Alternaria alternata in pot culture experiment during 2001-02.

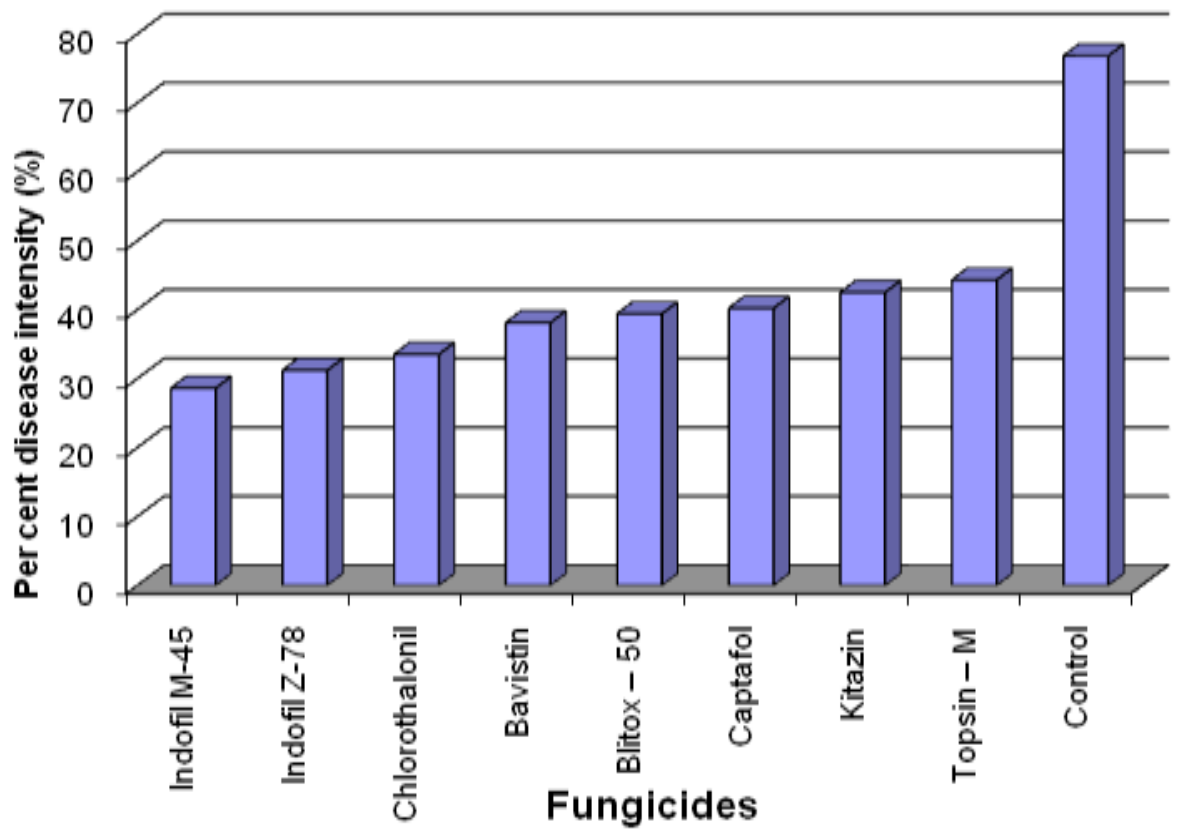


Fig.4

Fig. 4: Effect of fungicides spraying on the disease intensity of Alternaria leaf spot and fruit rot disease of chilli.

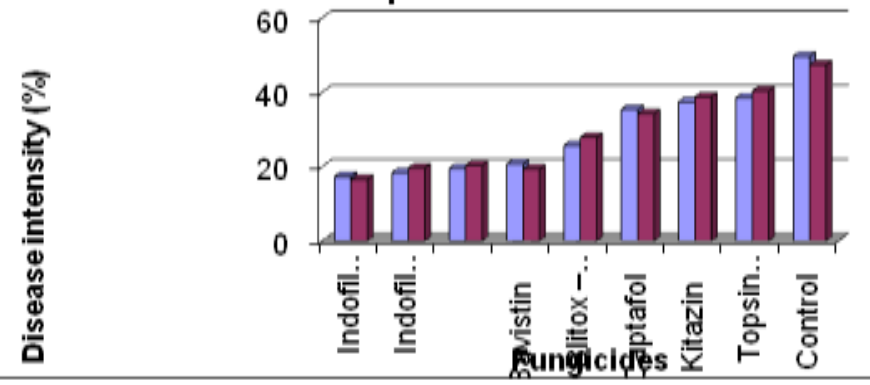

口Av. Disease intensity (\%) 2002-03 口Av. Disease intensity (\%)2003-04

Bavistin and Thiram for eliminating infection and significantly similar to each other. Other fungicides and bio-agents in descending order of superiority were Pseudomonas flourescens, Captan, Captafol and Ziram were found moderately effective in controlling infection, but were significantly superior to control. As already observed, most of the fungicides were found to be quite effective in mitigating the load of primary inoculums present on seed but failed to check the secondary spread of the disease, which is the most destructive phase. As such, seed treatment could hardly be recommended for the control of Alternaria leaf spot and fruit rot of chilli.

\section{Foliar application}

\section{Evaluation of fungicides in pot culture experiment}

On the results obtained in the laboratory screening, efficacy of eight spray fungicides was further investigated by foliar application on the highly susceptible chilli variety Chaman under pot culture experiment (Table 3 ).

The result of Table 3 and Figure 3 indicate that Indofil M-45 was the most effective fungicides for controlling the disease followed by Indofil Z-78 and Chlorothalonil were statistically similarly to each other. The next in order to superiority was Bavistin followed by Blitox-50, Captafol, Kitazin, Topsin-M which were at par to each other in controlling the diseases. Topsin $M$ which remained in the last on account of its poor performance was significantly superior to control (check) to reducing the intensity of the disease.

\section{Evaluation of fungicides in the field}

All the fungicides employed in pot culture experiments were further evaluated in field culture experiments were further evaluated in field experiments during the two consecutive years (2002-03 and 2003-04), in order to assess their efficacy in controlling the disease. The experiments were conducted in randomized block design with three replication. The method of inoculation and spraying schedule followed were the same as described under 'Material and Methods'. The data on disease intensity were recorded fifteen days after the last spraying and yield data were recorded during the crop season (Table 4).

It is evident from Table 4 and Figure 4 that in the year 2002-03, all the fungicides gave significantly better control of the disease as compared in check. In this season Indofil M-45 proved to be most effective in checking the disease, followed by Indofil Z-78 and Chlorothalonil. All these fungicides differed significantly but statistically at par to each other. The next in order to superiority was Bavistin, which was at par to Chlorothalonil, Blitox-50, Captafol, Kitazin and Topsin $\mathrm{M}$ in 
order of superiority were statistically superior to each other in controlling the disease but Captafol, Kitazin and Topsin $\mathrm{M}$ were at par to each other. In the year 2003-04, also all the fungicides gave significantly better control of the disease as compared to check. Indofil M-45 proved to be the most effective in checking the disease followed by Bavistin, Indofil Z-78 a Chlorothalonil, which were at par to each other. The remaining fungicides viz., Blitox-50 Captafol, Kitazin, Topsin M were found less effecting to controlling the disease. Among them Kitazin and Topsin $M$ were found statistically at par to each.

\section{References}

Agrios, G.N. (2004). Plant Pathology Academic Press, London, U.K. (IV Eds.) p. 803.

Alam, K.B., Bakr, A. and Ahmad, H.U. (1981). Fruit rot of pepper. FAO Plant Prot. Bull., 29 (1/2): 28-29.

Bliss, C.J. (1934). The methods of probits. Science 79: 38.

Govindrajan, V.S. (1985). Capsicum production technology, chemistry and quality. Part II. Processed products standards, world production and trade. C.R.C. Critical Review in Nut. 23(3): 207-288.

Leyendecker, P. J. (1954 a). Fungi associated with internal contamination of sun dried chilli in New Mexico. Bull. Torrey. Bot. Soc., 81(5): 400-404.

Maya, J.A. (1975). Capsicum. C.R.C. Critical Review in Food, Sci., Nut., 6(2): 177193.

Mathur, R.L. and Agnihotri, J.P. (1961). Internal moulds of chilli caused by Alternaria tenuis Auct. Indian Phytopath., 14: 104-105.

Mehrotra, R.S. (1980). Plant Pathology. Tata McGraw Hill Pub. Co. Ltd., New Delhi. p 770 .

Mukherji, K.G. and Bhasin, J. (1986). Plant Diseases of India- A Source Book. Tata McGraw Hill Pub. Co. Ltd., New Delhi. P 468.

Mukhopadhyay, A.N. (1969). Two Alternaria disease of sugarbeat in India. Indian Phytopath., 22: 135-138.

Narain, U.; Kumar, K. and Srivastava, M. (2000). Advances in Plant Disease Management. Advance Publishing Concept, New Delhi pp 163-173.

Nath, P. (1969). Vegetables for the Tropical Region. Indian Council of Agricultural Research, New Delhi, Book Series No. 2.

Purseglove, J.W. (1977). Tropical Crops. Dicotyledons I \& II. Longman, London, U.K. 135-136 pp.

Singh, R. S. (2003) Plant Pathology. Oxford and IBH Pub. Co., New Delhi, p. 564.

Schmitz, H. (1930). A suggested toximetric method for wood preservation. Indus and Engine. Chem. Analyst, ed. 11: 361363.

Spalding, D.H. and King, J.R. (1981). Inhibition of Alternaria rot of tomatoes and bell peppers by post harvest treatment with CGA 64251 or Imazalil. Proc. Florida State Hort. Soc., 93: 303-307.

Tiwari, V.P. (1990). Development of high capsaicin chillies (Capsicum annuum L.) and their implications for the manufacture of export products. J. Plant Crops. 18 (1): 1-13.

Vicent, A.; Armengol, J.; Sales, R.; GarciaJimenez, J. and Alfaro-Lassala, F. (2000) First report of Alternaria brown spot of citrus in Spain. Plant. Dis., 84 (9): 1044.

\section{How to cite this article:}

Manjul Pandey, P.K. Dwivedi, R.P. Mishra and Mukesh Srivastava. 2019. Evaluation of Various Fungitoxicants and Bio-Agents in the Laboratory and Field against Leaf Spot and Fruit Rot of Chilli caused by Alternaria alternata (Fries) Keissler. Int.J.Curr.Microbiol.App.Sci. 8(01): 28502859. doi: https://doi.org/10.20546/ijcmas.2019.801.299 